\title{
The course of bronchial asthma associated with metabolic syndrome in children with different phenotypes depending on vitamin $D_{3}$ level
}

\author{
T. L. Protsiuk ${ }^{1}$, Ye. V. Herasymova ${ }^{1}$, L. O. Protsiuk ${ }^{1}$, N. M. Surkova ${ }^{2}$ \\ ${ }^{1}$ National Pirogov Memorial Medical University, Vinnytsia, Ukraine, ${ }^{2}$ Vinnytsia Regional Children's Clinical Hospital, Ukraine
}

Key words:

asthma, metabolic

syndrome, children, vitamin D3.

Pathologia 2018; $15(1), 68-72$

DOI:

10.14739/2310-1237.

2018.1.129321

E-mail:

rossata@ukr.net
Objective: to establish specific features of BA course in children with various phenotypes on the background of metabolic syndrome, depending on serum vitamin $D_{3}$ level.

Subjects and methods. 106 children with BA participated in the study. 42 patients had BAassociated with metabolic syndrome (MS), and 64 had BA with no MS. By the phenotype 61 (57.5\%) of patients had allergen-induced (allergic) asthma and 45 (42.5\%) - virus-induced (non-allergic) BA. The control group consisted of 44 children (the patients with MS and those without MS and BA), average age $15.5 \pm 1.3$ years. All the patients underwent a unified complex of diagnostic investigations: general physical examination, measurement of waist circumference and body mass index (BMI), clinical blood test, spirometry, lipid profile. Weight categories (normal weight, excess weight and obesity) were determined by percentiles $(P)$ of BMI variation series with regard to age, as indicated in WHO recommendations. Serum $25(\mathrm{OH}) \mathrm{D}$ levels were determined by enzyme immunoassay. Vitamin D level $\geq 20 \mathrm{ng} / \mathrm{ml}$ was considered sufficient, $11-20 \mathrm{ng} / \mathrm{ml}$ - insufficient, $\leq 10 \mathrm{ng} / \mathrm{ml}$ - deficient. General and specific serum IgE levels were determined by enzyme immunoassay. The data obtained were processed with Statistica 8 program, $P$ values of less than 0.05 were considered to indicate statistical significance.

Results. In the group of patients with vitamin $\mathrm{D}_{3}$ level below $20 \mathrm{ng} / \mathrm{ml}, 19.5 \%$ had controlled BA and $41.3 \%$ - uncontrolled $\mathrm{BA}$, while among the children with vitamin $\mathrm{D}_{3}$ level over $20 \mathrm{ng} / \mathrm{ml}, 30.4 \%$ had controlled BA and $8.6 \%$ - uncontrolled BA $\left(X^{2}=9.12, P<0.05\right)$. Mean value of vitamin $D_{3}$ concentration in the control group was significantly higher than in the patients with $B A$ associated with MS and BA without MS $(P<0.05)$. The relationship between $O W$, obesity and atopy was confirmed by high serum level of slgE antibodies in those weight categories. High slgE levels to allergens from the pollen of meadow grass, weeds and trees, animal epithelium, household dust mite, food and fungal allergens were determined much more frequently in the children with OW and obesity than in those with NW. In the patients with BA associated with MS and vitamin $\mathrm{D}_{3}$ level below $20 \mathrm{ng} / \mathrm{ml}$, FEV1 and FVLC values appeared to be significantly lower as compared to those with vitamin $\mathrm{D}_{3}$ level over $20 \mathrm{ng} / \mathrm{ml}(P=0.002)$. Inverse relationship between the most important parameters of external respiration function and BMI was established: VLC $\left(r_{x y}=-0.45, P=0.002\right), F V L C\left(r_{x y}=-0.52, P=0.001\right), F E V 1\left(r_{x y}=-0.78, P=0.001\right)$, respectively.

Conclusions. The severity of BA as well as the degree of its control in the patients with different phenotypes was found to be influenced by both the presence of $M S$ and vitamin $D_{3}$ level. Therefore, vitamin $D$ deficiency can be one of the risk factors of BA and MS development, and can affect the severity of both BA and MS course. Vitamin $D_{3}$ deficiency and the presence of MS greatly influence FEV1, FVLC, PEF values, decreasing the indices of external respiration in children and leading to more severe obstruction.

\section{Ключові слова:}

бронхіальна астма, метаболічний синаром, Аіти, вітамін D3.

Патологія. - 2018. T. 15, № 1(42). -

C. 68-72

\section{Особливості перебігу бронхіальної астми на тлі метаболічного синдрому в дітей із різними фенотипами залежно від показників вітаміну $\mathrm{D}_{3}$}

\section{Т. А. Процюк, О. В. Герасимова, А. О. Процюк, Н. М. Суркова}

Мета роботи - встановити особливості перебігу бронхіальної астми (БА) у дітей із різними фенотипами на тлі метаболічного синдрому залежно від рівня вітаміну $\mathrm{D}_{3}$ в сироватці крові.

Матеріали та методи. У дослідженні взяли участь 106 дітей, хворих на БА: 42 дитини з діагнозом БА в поєднанні 3 метаболічним синдромом (МС), 64 дитини з БА без МС. Алерген-індукований фенотип встановили у 57,5\% хворих на БА, вірус-індукований - у 42,5\%. Група контролю - 44 дитини (пацієнти з МС і без МС і БА), середній вік - 15,5 $\pm 1,3$ року. Всім хворим виконали єдиний комплекс діагностичних досліджень: загальне фізикальне обстеження, визначення обводу талії та індексу маси тіла (IMT), аналіз крові клінічний, спірометрія, визначення ліпідного спектра. Вагові категорії (нормальна, надмірна вага та ожиріння) визначали за перцентилями (Р) варіаційного ряду IMT з урахуванням віку відповідно до рекомендацій BOO3. Рівні 25-(OH)D у сироватці крові визначили за допомогою імуноферментного аналізу. Рівень вітаміну $\mathrm{D}_{3} \geq 20$ нг/мл розцінювали як достатній, 11-20 нг/мл - недостатній, $\leq 10$ нг/мл - дефіцит. Загальний і специфрічні рівні сироваткових IgЕ визначили за допомогою ІФА. Результати опрацювали в програмі Statistica 8, статистично вірогідними вважали розбіжності при $p<0,05$.

Результати. У групі хворих із рівнем вітаміну $\mathrm{D}_{3}$ нижче ніж 20 нг/мл пацієнти з контрольованим перебігом БА становили $19,5 \%$, а з неконтрольованим - 41,3\%; серед хворих із рівнем вітаміну $D_{3}$ понад 20 нг/мл контрольований перебіг БА встановили у 30,4 \% пацієнтів, неконтрольований - у 8,6 \% ( $\left.X^{2}=9,12, p<0,05\right)$. Середній показник концентрації вітаміну $\mathrm{D}_{3}$ в контрольній групі був вірогідно вищим, ніж у групах хворих на БА в поєднанні з МС і БА без МС $(p<0,05)$. У дітей із надмірною масою тіла та ожирінням значно частіше, ніж у дітей із нормальною вагою, визначали високі рівні slgE до алергенів із пилку лучних трав, бур'янів і дерев, епітелію тварин, кліщів побутового пилу, харчових і грибкових алергенів. У хворих на БА в поєднанні з МС і показниками рівня вітаміну $\mathrm{D}_{3}$ нижче ніж 20 нг/мл, показники ОФВ, і ФЖЕЛ виявилися вірогідно нижчими порівняно з пацієнтами з рівнем вітаміну $D_{3}$ понад 20 нг/мл ( $\left.p=0,002\right)$. Встановили зворотний взаємозв'язок найбільш значущих параметрів функції зовнішнього дихання з IMT: ЖЕЛ $\left(r_{x y}=-0,45, p=0,002\right)$, ФЖЕЛ $\left(r_{x y}=-0,52, p=0,001\right)$, ОФВ ${ }_{1}\left(r_{x y}=-0,78, p=0,001\right)$ відповідно. 
Висновки. Важкість і контрольованість перебігу БА у хворих із різними фенотипами залежить як від наявності МС, так і від рівня вітаміну $\mathrm{D}_{3}$, десріцит вітаміну $\mathrm{D}_{3}$, відповідно, може бути одним із факторів ризику розвитку БА i MC, а також

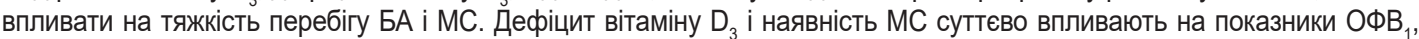
ФжЄЛ, ПШВ, знижуючи показники зовнішнього дихання в дітей, призводять до більш виражених обструктивних змін.

\section{Особенности течения бронхиальной астмы на фоне метаболического синдрома у детей с различными фенотипами в зависимости от показателей витамина $\mathrm{D}_{3}$}

\section{Т. А. Процюк, Е. В. Герасимова, А. А. Процюк, Н. М. Суркова}

Цель работы - установить особенности течения бронхиальной астмы (БА) у детей с различными фенотипами на фоне метаболического синдрома в зависимости от уровня витамина $\mathrm{D}_{3}$ в сыворотке крови.

Материалы и методы. В исследовании приняли участие 106 детей, больных БА: 42 ребенка с диагнозом БА в сочетании с метаболическим синдромом (МС), 64 ребенка с БА без МС. Аллерген-индуцированный френотип установлен у 57,5 \% больных, вирус-индуцированный - у 42,5 \%. Группа контроля состояла из 44 детей (пациенты с МС и без МС и БА), средний возраст - 15,5 $\pm 1,3$ года. Всем больным проведен единый комплекс диагностических исследований: общее физикальное обследование, установление окружности талии и индекса массы тела (ИМТ), клинический анализ крови, спирометрия, определение липидного спектра. Весовые категории (нормальная, избыточный вес и ожирение) определяли по перцентили (Р) вариационного ряда ИМТ с учетом возраста в соответствии с рекомендациями ВОЗ. Уровни 25-(OH)D в сыворотке крови, показатели общего и специфических уровней сывороточных IgE определяли с помощью ИФА. Уровень витамина $\mathrm{D}_{3} \geq 20$ нг/мл расценивали как достаточный, 11-20 нг/мл - недостаточный, $\leq 10$ нг/мл дефицит. Результаты обработали в программе Statistica 8, статистически достоверными считали различия при p < 0,05.

Результаты. В группе детей с уровнем витамина $\mathrm{D}_{3}$ ниже 20 нг/мл больные с контролируемым течением БА составили 19,5 \%, с неконтролируемым - 41,3\%; среди больных с уровнем витамина $\mathrm{D}_{3}$ более 20 нг/мл контролируемое течение БА установлено у 30,4\% пациентов, неконтролируемое - у 8,6 \% ( $\left.\chi^{2}=9,12, p<0,05\right)$. Средний показатель концентрации витамина $\mathrm{D}_{3}$ в контрольной группе достоверно выше, чем в группах больных БА в сочетании с MC и БА без МС $(p<0,05)$. У детей с избыточной массой тела и ожирением значительно чаще, чем у детей с нормальным весом определены высокие уровни slgE к аллергенам из пыльцы луговых трав, сорняков и деревьев, эпителия животных, клещей бытовой пыли, пищевым и грибковым аллергенам. У больных БА в сочетании с МС и показателями уровня витамина $\mathrm{D}_{3}$ ниже 20 нг/мл показатели ОФВ и ФЖЕЛ оказались достоверно ниже по сравнению с больными с уровнем витамина $\mathrm{D}_{3}$ более 20 нг/мл $(p=0,002)$. Установлена обратная взаимосвязь наиболее значимых параметров функции внешнего дыхания с избыточной массой тела: ЖЕЛ ( $\left.r_{x y}=-0,45, p=0,002\right)$, ФЖЕЛ $\left(r_{x y}=-0,52, p=0,001\right), 0 Ф B_{1}$ $\left(r_{x y}=-0,78, p=0,001\right)$.

Выводы. Тяжесть и контролируемость БА у больных с различными фенотипами зависит как от наличия МС, так и от уровня витамина $\mathrm{D}_{3}$, дефицит витамина $\mathrm{D}_{3}$, соответственно, может выступать одним из факторов риска развития БА и МС, а также влиять на тяжесть течения БА и МС. Дефицит витамина $\mathrm{D}_{3}$ и наличие МС существенно влияют на показатели ОФВ обструктивным изменениям.

Bronchial asthma $(B A)$ is currently the most prevalent chronic disease in pediatric patients. For more than a century, clinicians have attempted to subdivide asthma into different phenotypes based on triggers that cause asthma attacks, the course of the disease, or the prognosis. Asthma is a heterogenous disorder that can be classified into several different phenotypes. The first phenotypes that were described included allergic asthma, nonallergic asthma or infectious asthma, and aspirin-exacerbated asthma. Asthma phenotypes were initially focused on combinations of clinical characteristics [1].

Allergic asthma is the most common asthma phenotype. Allergen-induced (allergic asthma): this is the asthma phenotype, which often commences in childhood and is associated with a past and/or family history of allergic disease such as eczema, allergic rhinitis, or food or drug allergy. The average age of onset of allergic asthma is younger than that of nonallergic asthma. Although the spectrum of allergic asthma may vary from mild to severe, studies have reported that allergic versus nonallergic asthma is less severe. Total IgE levels usually are higher in allergic versus nonallergic asthma, but levels substantially overlap between the 2 groups. Virus-induced (non-allergic) asthma: this is the asthma phenotype which is not associated with allergy. Virus-induced asthma is a phenotype which is characterized by a sudden onset and sometimes a severe clinical course. Each viral infection may alter the course of preexisting asthma, or can affect the immune system and subsequently modify the susceptibility to allergen sensitization and asthma in childhood.

Recent cluster analyses have identified an "obese-asthma" phenotype which is characterized by late onset and lack of atopy. In addition, obesity among early-onset asthmatics clearly exists and heightens the clinical presentation. Observational studies have demonstrated that asthma among the obese has a clinical presentation that is more severe, harder to control, and is not as responsive to standard controller therapies [2].

Along with such classic risk factors for BA development as sex, age, family allergic anamnesis, atopy manifestations, eosinophilia, increased body mass index $(\mathrm{BMI})$, there are several factors which can influence the severity of $B A$, vitamin $D_{3}$ deficiency being one of them. The study of potential effect of vitamin $D_{3}$ deficiency on BA course is of great significance because of its ability to influence the cellular and humoral immunity, thus decreasing the inflammatory process [3], as well as due to the predisposition to frequent respiratory diseases in
Киючевые слова:

бронхиальная астма, метаболический синаром, Аети, витамин D3.

Патология. - 2018. -

T. 15, № 1(42). C. $68-72$ 
case of its deficiency. This mechanism is caused by gene expression and cytokine synthesis. A great number of scientific studies demonstrate the relationship between vitamin $D_{3}$ level and frequency and severity of viral, bacterial and fungal infection course. Besides, negative correlation was found between infectious process activity, the number of complications and vitamin $D_{3}$ level. The major mechanism of vitamin $D_{3}$ anti-infectious action is its ability to induce the formation of $\beta$-defensin- 2 and cathelicidin in macrophages, neutrophils, natural killers (NK-cells) and epithelial cells, destroying microorganisms and being active to bacteria, viruses and fungi. Sufficient level of $25(\mathrm{OH}) \mathrm{D}_{3}$ supply is associated with increased number of circulating Th1-cells which induce the secretion of anti-inflammatory cytokines ( $\mathrm{Y}$-interferon, IL-2, IL-12, TNF- $\alpha$ ), while decreased serum $25(\mathrm{OH}) \mathrm{D}_{3}$ level is followed by activation of Th2-immune response, i.e. by the increase in IL-4, IL-5, IL-13 populations, promoting atopic reactivity of the body. Besides, overweight and obesity were recently found to be caused by low vitamin $D_{3}$ level [4], in part, due to high similarity of calcitriol and vitamin $D_{3}$ receptor. Vitamin $D_{3}$ receptors and vitamin $D$ metabolic enzymes were found in many cells: T- and B-lymphocytes, macrophages, including lung alveolocytes and bronchial smooth muscles [5]. Asthma-related morbidity is higher among children with vitamin $D_{3}$ deficiency and obesity, morbidities that frequently co-exist among minority children. However, the effect of co-existent obesity and vitamin $D_{3}$ deficiency on pulmonary function is poorly understood [6].

Though many reports on the problem discussed have already been published, the molecular mechanisms of non-classic action of vitamin $D_{3}$ are still unstudied. This can be explained by insufficient number of randomized studies to assess the impact of vitamin $D_{3}$ on metabolic processes and BA course.

\section{Objective}

To establish specific features of BA course in children with various phenotypes on the background of metabolic syndrome, depending on serum vitamin $\mathrm{D}_{3}$ level.

\section{Materials and methods}

106 children with BA (age $-15.8 \pm 1.8$ years, $\left.\mathrm{BMI}=10.2 \pm 0.57 \mathrm{~kg} / \mathrm{m}^{2}\right)$ participated in the study. By the phenotype $61(57,5 \%)$ of patients had allergen-induced (allergic) asthma and 45 (42,5\%) - virus-induced (non-allergic) BA. 42 patients had BA associated with metabolic syndrome (MS), and 64 had BA with no MS. The control group consisted of 44 children (the patients with MS and those without MS and BA), average age $15.5 \pm 1.3$ years. BA severity, the phenotype, the level of BA control were evaluated by GINA 2011 criteria and "Protocol of diagnosis and treatment of bronchial asthma in children", approved by the Order of the Ministry of Health of Ukraine of October 8, 2013".

All the patients underwent a unified complex of diagnostic investigations: general physical examination, measurement of waist circumference and body mass index (BMI), clinical blood test, spirometry, lipid profile. Weight categories (normal weight, excess weight and obesity) were determined by percentiles $(P)$ of $B M I$ variation series with regard to age, as indicated in WHO recommendations ("Classification of BMI in children and adolescents"). In accordance with this classification, the children with $\mathrm{BMI}$ corresponding to P5 of variation series, were referred to under-normal weight category; those with BMI corresponding to P5-P84 - to normal weight group; P85-P94 - to excess weight group, and over P94 - to obesity group. Serum $25(\mathrm{OH}) \mathrm{D}_{3}$ levels were determined by enzyme immunoassay. Blood sampling was done in winter period. In accordance with the recommendations of the US Institute of Medicine, vitamin $D_{3}$ level $\geq 20 \mathrm{ng} / \mathrm{ml}$ was considered sufficient, $11-20 \mathrm{ng} / \mathrm{ml}$ - insufficient, $\leq 10 \mathrm{ng} / \mathrm{ml}$ - deficient. General and specific serum $\mathrm{lgE}$ levels were determined by enzyme immunoassay. All the analysis were done from 9 to 11 a.m.

Statistical data processing was done with Statistical package for Windows v. 8.0 (№ AXXR910A374605FA) using parametric methods. The normal distribution was evaluated according to Shapiro-Wilk test. Digital information of all clinical investigations was processed by variance statistical method calculating the mean value (M) and its error ( $m$ ). The comparison of quality indicators was performed using the $x^{2}$ criterion. The conjugacy coefficient $(\varphi)$ was determined to estimate the strength of the relationship between the features. Odds ratios (OR) and the corresponding $95 \%$ confidence intervals $(\mathrm{Cl})$ were used to compare the quantitative indices of the two characteristics. The significance of difference between two means was calculated by Student's t-test (t). Correlation analysis with calculation of Pearson's correlation $\left(r_{x y}\right)$ was used to establish the relationship between the studied indices. Differences were considered significant if significance value was $95 \%(P<0.05)$.

\section{Results and discussion}

Intermittent, mild, moderate and severe BA were diagnosed in $13 \%, 39 \%, 39 \%$ and $9 \%$ of patients, respectively, by physical and instrumental examination. By etiology $39 \%$ of patients had allergic, $26 \%$ - mixed and $35 \%$ - non-allergic BA. In $50 \%$ of patients BA was controlled and in $50 \%$ - uncontrolled. All the patients were divided into three weight categories by BMl: those with normal weight (NW) $-34.1 \%$, overweight (OW) $-34.6 \%$ and obesity $-31.3 \%$ of children.

Having grouped all the children according to their weight and age, we found an increased number of children with obesity in pubertal age (OR $=3.6 ; 95 \% \mathrm{Cl}$ : 1.14-11.35; $\mathrm{P}=0.003 ; \mathrm{OR}=9.0 ; 95 \% \mathrm{Cl}: 1.56-51.87$; $\mathrm{P}=0.008$ and $\mathrm{OR}=3.71 ; 95 \% \mathrm{Cl}: 1.06-12.98 ; \mathrm{P}=0.04$, respectively). And the number of obese children decreased together with the increase of age $(\mathrm{OR}=0.28$; $95 \% \mathrm{Cl}: 0.09-0.88 ; \mathrm{P}=0.003 ; \mathrm{OR}=0.11 ; 95 \% \mathrm{Cl}: 0.02$ $0.63 ; \mathrm{P}=0.008 ; \mathrm{OR}=0.27 ; 95 \% \mathrm{Cl}: 0.08-0.94 ; \mathrm{P}=0.04$, respectively). No relationship between obesity and sex in BA children were found, but a tendency to increased obesity in males as compared to females $(P=0.059)$ was observed. Besides, the relationship between body weight and clinical manifestations of allergy was found. Among the children suffering from atopic BA, $37.4 \%$ had excess weight, $34.3 \%$ - obesity , $28.3 \%$ - normal weight, while 
among those with mixed BA overweight was found in $25 \%$, obesity - in $20.8 \%$, and normal weight - in $54.2 \%$ of patients. More than a half of the patients with non-atopic BA $(58.7 \%)$ had normal body weight. The children with atopic $\mathrm{BA}$ were found to have overweight $(\mathrm{OR}=2.86$; $95 \% \mathrm{Cl}: 1.31-6.25 ; \mathrm{P}=0,005)$ and obesity $(\mathrm{OR}=3.15$; $95 \% \mathrm{Cl}: 1.38-7.20 \mathrm{P}=0.007$ ) significantly more often as compared to the patients with non-atopic BA.

In the group of patients with BA associated with MS as well as those with BA with no MS there were $32 \%$ of children with vitamin $D_{3}$ deficiency, $42 \%$ - with vitamin $D_{3}$ insufficiency, and $26 \%$ - with sufficient level of Vitamin $D_{3}$. In the control group there were $33 \%$ of patients with vitamin $D_{3}$ deficiency, $9 \%$ - with vitamin $D_{3}$ insufficiency, and $58 \%$ - with sufficient vitamin $D_{3}$ level. Vitamin $D_{3}$ level was largely influenced by the severity of BA. It was $19.8 \pm 5.0 \mathrm{ng} / \mathrm{ml}$ in intermittent, $17.3 \pm 5.9 \mathrm{ng} / \mathrm{ml}$ - in mild; $14.9 \pm 4.2 \mathrm{ng} / \mathrm{ml}$ - in moderate; $12.8 \pm 4.6 \mathrm{ng} / \mathrm{ml}-$ in severe $B A ; P<0.05$.

The level of BA control and comorbidity were influenced by the level of vitamin $D_{3}$ as well. In the group of patients with BA associated with MS as well as in those with $B A$ and no $M S$ vitamin $D_{3}$ level was significantly lower in the children with uncontrolled BA $(P=0.005)$. It was $18.9 \pm 4.9 \mathrm{ng} / \mathrm{ml}$ in the group of patients with controlled $\mathrm{BA}$ and $12.6 \pm 2.7 \mathrm{ng} / \mathrm{ml}-$ in those with uncontrolled BA $(\mathrm{t}=3.2, \mathrm{P}=0.005)$.

The patients with vitamin $D_{3}$ deficiency were found to have uncontrolled BA four times as often as the children with normal levels of vitamin $D_{3}$. In the group of patients with vitamin $\mathrm{D}_{3}$ level below $20 \mathrm{ng} / \mathrm{ml}, 19.5 \%$ had controlled $\mathrm{BA}$ and $41.3 \%$ - uncontrolled BA, while among the children with vitamin $\mathrm{D}_{3}$ level over $20 \mathrm{ng} / \mathrm{ml}, 30.4 \%$ had controlled BA and $8.6 \%$ - uncontrolled BA $\left(X^{2}=9.12, P<0.05\right)$. Mean value of vitamin $D_{3}$ concentration in the control group was significantly higher than in the patients with BA associated with $M S$ and $B A$ without MS $(P<0.05)$. BMI in the patients with vitamin $D_{3}$ level below $20 \mathrm{ng} / \mathrm{ml}$ was found to be significantly higher than among the children with vitamin $\mathrm{D}_{3}$ level over $20 \mathrm{ng} / \mathrm{ml}$. Mean value of BMl in the patients with vitamin $D_{3}$ level below $20 \mathrm{ng} / \mathrm{ml}$ was $32.8 \pm 3.4$ while among the children with vitamin $D_{3}$ level over $20 \mathrm{ng} / \mathrm{ml}$ it was $29.01 \pm 5.1(t=2.49, P=0.01)$, respectively. E. Forno, J. C. Celedón [7] found it was obesity increases the risk of asthma - and worsens asthma severity or control - via multiple mechanisms. "Obese asthma" is a complex, multifactorial phenotype in children.

Significant increase in triglycerides and cholesterol levels was revealed in the patients with BA together with the decrease of vitamin $D_{3}$ level $(P<0.05)$. There was negative correlation between the level of low density lipoproteins and vitamin $D_{3}$ level $\left(r_{x y}=-0.58, P=0.008\right)$, while the level of high density lipoproteins increased together with the increase of vitamin $D_{3}$ level $(P=0.06)$. No statistically significant differences between the levels of vitamin $D_{3}$ and total $\lg E$ were found $(P>0.05)$. Having analyzed immunologic indices, high level of total lgE was revealed practically in all the children with allergic and mixed $\mathrm{BA}$, ranging from 300 to $600 \mathrm{IU} / \mathrm{ml}$, and reaching $1500-2000 \mathrm{IU} / \mathrm{ml}$ in some patients. Statistical analysis showed obese children to have higher total $\lg$ E level (2.7; $95 \% \mathrm{Cl}: 2.64-2.84)$ as compared to those with
OW (2.46; $95 \%$ Cl: 2.40-2.60) and NW (2.37; $95 \%$ Cl: 2.30-2.50). Study of the relationship between IgE level and body weight demonstrated that the children with $\mathrm{OW}$ not always had high total IgE level $(\mathrm{OR}=1.86$; $95 \% \mathrm{Cl}$ : $0.70-5.09, P=0.21$ ) as compared to the children with $\mathrm{NW}$, while obese children appeared to have higher total lgE level $(\mathrm{OR}=4.20 ; 95 \% \mathrm{Cl}: 1.13-15.60, \mathrm{P}=0.02)$ than those with normal weight. With high probability $(P=0.02)$ of correlation $\left(X^{2}=4.56\right)$ between body weight and total $\lg \mathrm{E}$ level, strong degree of this association $(\varphi=0.59)$ was found as well. The relationship between OW, obesity and atopy was confirmed by high serum level of slgE antibodies in those weight categories. High slgE levels to allergens from the pollen of meadow grass, weeds and trees, animal epithelium, household dust mite, food and fungal allergens were determined much more frequenty in the children with OW and obesity than in those with NW. The proportion of patients with NW, OW and obesity having slgE to meadow grass pollen was $51.7 \%, 60.2 \%$ and $84.9 \%$ respectively; to weeds $-50.3 \%, 78.6 \%$, $85.7 \%$, respectively; to trees $-25.8 \%, 43.7 \%, 70.8 \%$, respectively; to epidermal allergens - $56.5 \%, 72.8 \%$, $82.3 \%$, respectively; and to food allergens $-50.6 \%$, $55.7 \%, 59.8 \%$, respectively. Besides, obesity in BA children was associated with sensitization to considerably greater number of allergens, namely: to allergens from the pollen of meadow grass $(\mathrm{OR}=6.10 ; 95 \% \mathrm{Cl}$ : $1.78-3.57 ; P=0.0001)$, weeds $(\mathrm{OR}=5.0 ; 95 \% \mathrm{Cl}: 1.43-$ 8.53; $\mathrm{P}=0.006)$, trees $(\mathrm{OR}=4.56 ; 95 \% \mathrm{Cl}: 1.72-10.0$; $P=0.004)$, animal epithelium allergens $(O R=4.58$; $95 \%$ Cl: 1.34-7.25; $\mathrm{P}=0.003$ ), food (OR = 4.00; $95 \%$ $\mathrm{Cl}: 1.02-6.86 ; \mathrm{P}=0.004)$, household dust mite allergens (OR $=3.68 ; 95 \% \mathrm{Cl}: 1.18-7.08 ; \mathrm{P}=0.001)$ and fungus (OR $=2.15 ; 95 \% \mathrm{Cl}: 1.39-5.39 ; \mathrm{P}=0.002$ ).

Significant decrease of forced expiratory volume in 1 second $\left(F_{1}\right)$ and forced vital lung capacity (FVLC), peak expiratory flow rate (PEF) were detected in $\mathrm{BA}$ patients as compared to normal values $(P=0.01$ and $P<0.001$, respectively). FEV1 decrease by $0.49 \%$ (95\% Cl: 0.69-0.15), FVLC - by $0.38 \%(95 \% \mathrm{Cl}: 0.56-0.14)$, and PEF - by $0.42 \%$ (95\% Cl: 0.42-0.17) with every unit of BMl increase were revealed in the patients with BA associated with MS. Besides, significant decrease of $\mathrm{FEV}_{1}$ values was demonstrated to be influenced by vitamin $D_{3}$ level. In the patients with $B A$ associated with MS and vitamin $D_{3}$ level below $20 \mathrm{ng} / \mathrm{ml}, \mathrm{FEV}_{1}$ and FVLC values appeared to be significantly lower as compared to those with vitamin $D_{3}$ level over $20 \mathrm{ng} / \mathrm{ml}(P=0.002)$. Mean value of vitamin $D_{3}$ concentration in the control group was significantly higher than in the patients with $B A$ associated with MS and BA without MS $(P=0.003)$. Inverse relationship between the most important parameters of external respiration function and BMI was established: $\operatorname{VLC}\left(r_{x y}=-0.45, P=0.002\right), F V L C\left(r_{x y}=-0.52, P=0.001\right)$, FEV1 $\left(r_{x y}=-0.78, P=0.001\right)$, respectively.

L. A. Lautenbacher et al. [6] found that vitamin $D_{3}$ deficiency was associated with pulmonary function deficits among obese children, but not among normal-weight children with asthma, an association that was independent of Th1 and Th2 serum inflammatory measures. Vitamin $D_{3}$ deficiency may be one potential mechanism underlying the obese-asthma phenotype. 


\section{Conclusions}

1. The severity of BA as well as the degree of its control in the patients with different phenotypes was found to be influenced by both the presence of MS and vitamin $D_{3}$ level. Therefore, vitamin $D_{3}$ deficiency can be one of the risk factors of $\mathrm{BA}$ and $\mathrm{MS}$ development, and can affect the severity of both BA and MS course.

2. Vitamin $D_{3}$ deficiency and the presence of MS greatly influence FEV1, FVLC, PEF values, decreasing the indices of external respiration in children and leading to more severe obstruction.

The perspectives of further scientific research in this direction are to study the best ways of pharmacological therapy and rehabilitation in patients with $\mathrm{BA}$.

Конфлікт інтересів: віАсутній.

Conflicts of Interest: authors have no conflict of interest to declare.

Information about authors:

Protsiuk T. L., MD, PhD, DSc, Associate Professor

of the Department of Pediatrics № 1, National Pirogov Memorial

Medical University, Vinnytsia, Ukraine.

Herasymova 0. V., MD, PhD, Assistant of the Department

of Pediatrics №1, National Pirogov Memorial Medical University, Vinnytsia, Ukraine.

Protsiuk L. O., MD, PhD, Assistant of the Department of Hygiene and Ecology, National Pirogov Memorial Medical University, Vinnytsia, Ukraine.

Surkova N. M., Allergist, Vinnytsia Regional Children's Clinical Hospital, Ukraine.

Відомості про авторів:

Процюк Т. ^., А-р меА. наук, Аоцент каф. пеАіатрії № 1, Вінницький національний медичний університет імені М. І. Пирогова, Україна.

Герасимова О. В., канА. меА. наук, асистент каф. педіатрії № 1 , Вінницький національний медичний університет імені М. І. Пирогова, Україна.

Процюк ^. О., канА. меА. наук, асистент каф. загальної гігієни та екології, Вінницький національний меАичний університет імені М. І. Пирогова, Україна.

Суркова Н. М., ^ікар-алерголог, Вінницька обласна Аитяча киінічна мікарня, Україна.

\section{Сведения об авторах:}

Процюк Т. ^., А-р меА. наук, Аоцент каф. пеАиатрии № 1, Винницкий национальный медицинский университет имени Н. И. Пирогова, Украина.

Герасимова Е. В., канА. меА. наук, ассистент каф. педиатрии № 1, Винницкий национальный медицинский университет имени Н. И. Пирогова, Украина.

Процюк $\Lambda$. А., канА. меА. наук, ассистент каф. общей гигиены и экологии, Винницкий национальный меАицинский университет имени Н. И. Пирогова, Украина.

Суркова Н. М., врач-аммерголог, Винницкая областная детская клиническая больница, Украина.

Надійшла Ао реАакції / Received: 14.12.2017

Після Аоопрацювання / Revised: 20.02.2018

Прийнято Ао Аруку / Accepted: 26.02.2018

\section{References}

[1] Schatz, M., \& Rosenwasser, L. (2014) The allergic asthma phenotype. Allergy Clin Immunol Pract., 2(6), 645-8. doi: 10.1016/j. jaip.2014.09.004.

[2] Farzan, S. (2013) The asthma phenotype in the obese: distinct or otherwise. J. Allergy (Cairo)., 2013, 602-908. doi: 10.1155/2013/602908.
[3] Neyestani, T. R., Nikooyeh, B., Alavi-Majd, H., Shariatzadeh, N., Kalayi, A., Tayebinejad, N., et al. (2012) Improvement of vitamin D status via daily intake of fortified yogurt drink either with or without extra calcium ameliorates systemic inflammatory biomarkers, including adipokines, in the subjects with type 2 diabetes. J. Clin. Endocrinol. Metab., 97(6), 2005-2011. doi: 10.1210/jc.2011-3465.

[4] Haines, S. T., \& Park, S. K. (2012) Vitamin D supplementation: what's known, what to do, and what's needed. Pharmacotherapy, 32, 354-382. doi: 10.1002/phar.1037.

[5] Guillot, X. Semerano, L. \& Saidenberg-Kermanac, N. (2010) Vitamin $\mathrm{D}$ and inflammation. Joint Bone Spine., 77, 552-557.

[6] Lautenbacher, L. A., Jariwala, S. P., Markowitz, M. E., \& Rastogi, D. (2016) Vitamin D and Pulmonary Function in Obese Asthmatic Children. Pediatr Pulmonol, 51(12), 1276-1283. doi: 10.1002/ppul.23485.

[7] Forno, E., \& Celedón, J. C. (2017) The effect of obesity, weight gain and weight loss on asthma inception and control. Curr Opin Allergy Clin Immunol., 17(2), 123-130. doi: 10.1097/ACI.0000000000000339. 